\title{
Eighteen microsatellite loci developed from western burrowing owls (Athene cunicularia hypugaea)
}

\author{
Brant C. Faircloth • Alexandra Title • \\ Kevin Tan · Justin Welty · James R. Belthoff • \\ Patricia Adair Gowaty
}

Received: 18 February 2010/ Accepted: 20 February 2010/Published online: 12 March 2010

(C) The Author(s) 2010. This article is published with open access at Springerlink.com

\begin{abstract}
Western burrowing owls (Athene cunicularia hypugaea) are ground-dwelling owls distributed throughout western North America. Because of population declines, this species is considered endangered in Canada, and burrowing owls are listed as a species of conservation concern in states of the western USA. Korfanta et al. (2002) previously presented primers for seven microsatellite loci in burrowing owls. Parentage and relatedness studies require a larger number of markers for accuracy and precision. Here, we developed and characterized 18 additional microsatellite DNA loci, and we tested these loci in 23 individuals. The number of alleles per locus ranged
\end{abstract}

B. C. Faircloth $(\bowtie) \cdot$ P. A. Gowaty

Department of Ecology and Evolutionary Biology,

University of California, 621 Charles E. Young Drive South,

Los Angeles, CA 90095, USA

e-mail: brant.faircloth@gmail.com

A. Title

Department of Environmental Science, Policy \& Management, University of California, Berkeley, CA 94720, USA

K. Tan

Department of Microbiology, Immunology, and Molecular Genetics, University of California, Los Angeles, CA 90095, USA

J. Welty $\cdot$ J. R. Belthoff

Department of Biological Sciences and Raptor Research Center, Boise State University, Boise, ID 83725, USA

\section{P. A. Gowaty}

Institute of the Environment, University of California,

Los Angeles, CA 90095, USA

P. A. Gowaty

Smithsonian Tropical Research Institute, Unit 9100, Box 0948, DPO AA 34002-9998, USA from 2 to 11; two loci deviated from Hardy-Weinberg equilibrium following Bonferroni correction; we did not detect linkage disequilibrium following Bonferroni correction; and the probability of exclusion for parent pairs using all loci was $>0.9999$. We envision these loci will facilitate detailed analyses of the genetic mating system of burrowing owls, which is poorly understood.

Keywords Microsatellites - SSRs - Burrowing owls · Athene cunicularia $\cdot$ Strigidae

Western burrowing owls (Athene cunicularia hypugaea) are small, ground-dwelling owls native to western North America. These owls nest in underground burrows typically dug by mammals and lay clutches of up to 14 eggs. Sparse and low vegetation, such as that in grasslands and steppes, characterizes burrowing owl habitat (Haug et al. 1993), but owls can be abundant in agricultural areas (Conway et al. 2006; Moulton et al. 2006; Restani et al. 2008). Adult owls frequently nest in loose colonies (Lantz et al. 2007), but they also defend the space around their nests from conspecifics (Moulton et al. 2004). Northern burrowing owl populations are generally obligate migrants, whereas those to the south are year-round residents. Many populations have declined in abundance, often in response to the eradication of ground-dwelling mammals and/or loss of habitat. Thus, numerous American states list burrowing owls as a species of concern (Klute et al. 2003). Burrowing owls are federally endangered in Canada.

Korfanta et al. (2002) previously developed primers for seven microsatellite DNA loci and used these loci to investigate genetic variation among North American western burrowing owl populations (Korfanta et al. 2005). Their analyses also included comparisons between the 
disjunct western and Florida (A. c. floridana) subspecies of burrowing owls. Korfanta et al. (2005) found that populations within subspecies were essentially panmictic and genetic differentiation across subspecies was modest, although the western and Florida forms were easily distinguishable based on allelic absences in Florida populations, assignment tests, and well-supported branches on the inferred phylogenetic tree (Korfanta et al. 2005). Despite population declines, there was also no evidence for genetic bottlenecks (Korfanta et al. 2005).

Microsatellite loci have not been applied to studies of burrowing owl mating behavior or individual relatedness within nesting colonies, results of which interest conservation biologists and behavioral ecologists. Analysis of mating systems and relatedness is a task that requires a moderate to large number of genetic markers (Blouin 2003; Marshall et al. 1998; Milligan 2003; Selkoe and Toonen 2006). Thus, our objective was to develop a microsatellite panel sufficient to facilitate these studies that could be used alone or in combination with previously developed loci. Here we describe the isolation and characterization of 18 new microsatellite loci, building upon the panel previously developed by Korfanta et al. (2002).

We developed a double-enriched microsatellite library following Glenn and Schable (2005) and incorporating Invitrogen MyOne streptavidin beads (Invitrogen, Inc.; Faircloth et al. 2009) using DNA purified (5-Prime ArchivePure Blood Kit) from blood taken from a female burrowing owl collected in Idaho. From this library, we selected 760 positive (white) colonies using the $\beta$-galactosidase gene and bi-directionally sequenced 285 colony PCR products of 500-1,200 base pairs using 1/16th BigDye [v3.1, Applied Biosystems (ABI)] sequencing reactions and an ABI PRISM 3730xl sequencer. We aligned and edited sequences and assembled 184 contigs using Sequencher 4.2 (Gene Codes Corp.). We screened contigs against themselves, using BLAST (Altschul et al. 1990), to test for sequence homology, and we removed duplicate contigs. Using BLAST (Altschul et al. 1990), we also screened contigs for high-probability matches $(e$-score $=$ $1 \times 10^{-5}$ ) to burrowing owl sequences (Korfanta et al. 2002) present within GenBank (Benson et al. 2008). None of the contigs screened matched burrowing owl sequences within GenBank.

Using MSATCOMMANDER (Faircloth 2008), we located microsatellite repeat arrays within 59 contigs (32\%), designed 33 primers, and applied $5^{\prime}$-tags (CAG or M13R) to primer pairs for polymorphism testing (Boutin-Ganache et al. 2001; Glenn and Schable 2005). We manually designed primers $(N=12)$, for microsatellite-containing contigs where MSATCOMMANDER indicated primer design errors, using Oligo 6.0 (Molecular Biology Insights) and the $5^{\prime}$-tagging approach. We added GTTT "pigtails" to the $5^{\prime}$ end of all primers lacking either CAG or M13R tag to facilitate the addition of adenosine by $\mathrm{Taq}$ polymerase (Brownstein et al. 1996).

We tested 45 primer pairs for amplification using DNA collected from three burrowing owls using DNeasy kits (Qiagen Inc.). Prior to amplification, we treated DNA samples 1:1 (v/v) with $10 \%$ chelex resin (BioRad Laboratories), and we added $5 \mathrm{ng}$ DNA to each PCR reaction. We performed all PCR amplifications in $10 \mu \mathrm{L}$ volumes using ABI 9700 thermal cyclers in combination with the reaction mix and cycling parameters $\left(60^{\circ} \mathrm{C}\right.$ touchdown PCR; $-0.5^{\circ} \mathrm{C}$ step; Don et al. 1991) presented in Faircloth et al. (2009). We labeled M13R and CAG universal primers with VIC, NED, FAM or PET fluorescent dyes (ABI). We scored amplicons using an ABI Prism 3730xl DNA Sequencer in combination with LIZ600 fluorescent size standard (ABI), GeneMapper 4.0 Software (ABI) and the Local Southern size calling method.

Based on the performance of primers during the initial test, we selected 28 primer pairs for subsequent optimization and polymorphism testing. We did not select primer pairs for additional testing that were monomorphic $(N=10,22 \%)$ or failed to amplify cleanly $(N=7,16 \%)$ during the initial test.

Using DNA collected from 23 individual burrowing owls and purified with Qiagen DNeasy kits, we optimized and screened selected primers using conditions identical to those presented above. We did not produce and analyze amplicons using multiple annealing temperatures because a majority of peak morphologies were clear and easily resolved at a starting annealing temperature of $60^{\circ} \mathrm{C}$. We removed loci from the candidate set yielding ambiguous peaks or inconsistent results.

We calculated observed $\left(H_{\mathrm{O}}\right)$ and expected $\left(H_{\mathrm{E}}\right)$ heterozygosity, polymorphic information content (PIC), and exclusion probability using Cervus 3.0 (Marshall et al. 1998; Kalinowski et al. 2007), and we tested for deviations from Hardy-Weinberg equilibrium (HWE) and evaluated genotypic linkage disequilibrium (LD) using Genepop (Raymond and Rousset 1995). We conducted a posteriori Bonferroni correction (Rice 1989) for each analysis consisting of multiple, concurrent statistical tests (HWE and LD).

Table 1 presents the characteristics of 18 primer pairs amplifying microsatellite loci in burrowing owls. Amplification success was $99.3 \%$, and the number of alleles ranged from two to 11 , averaging 5.1. BOOB-BM4-H06 and BOOB-BM4-A01 deviated $(P<0.01)$ from HWE following Bonferroni correction, and we were unable to estimate deviation from HWE for BOOB-RM2-H08. We did not detect LD following Bonferroni correction. The exclusion probability for parent pairs was $>0.9999$. As indicated by the probability of exclusion, the microsatellite 


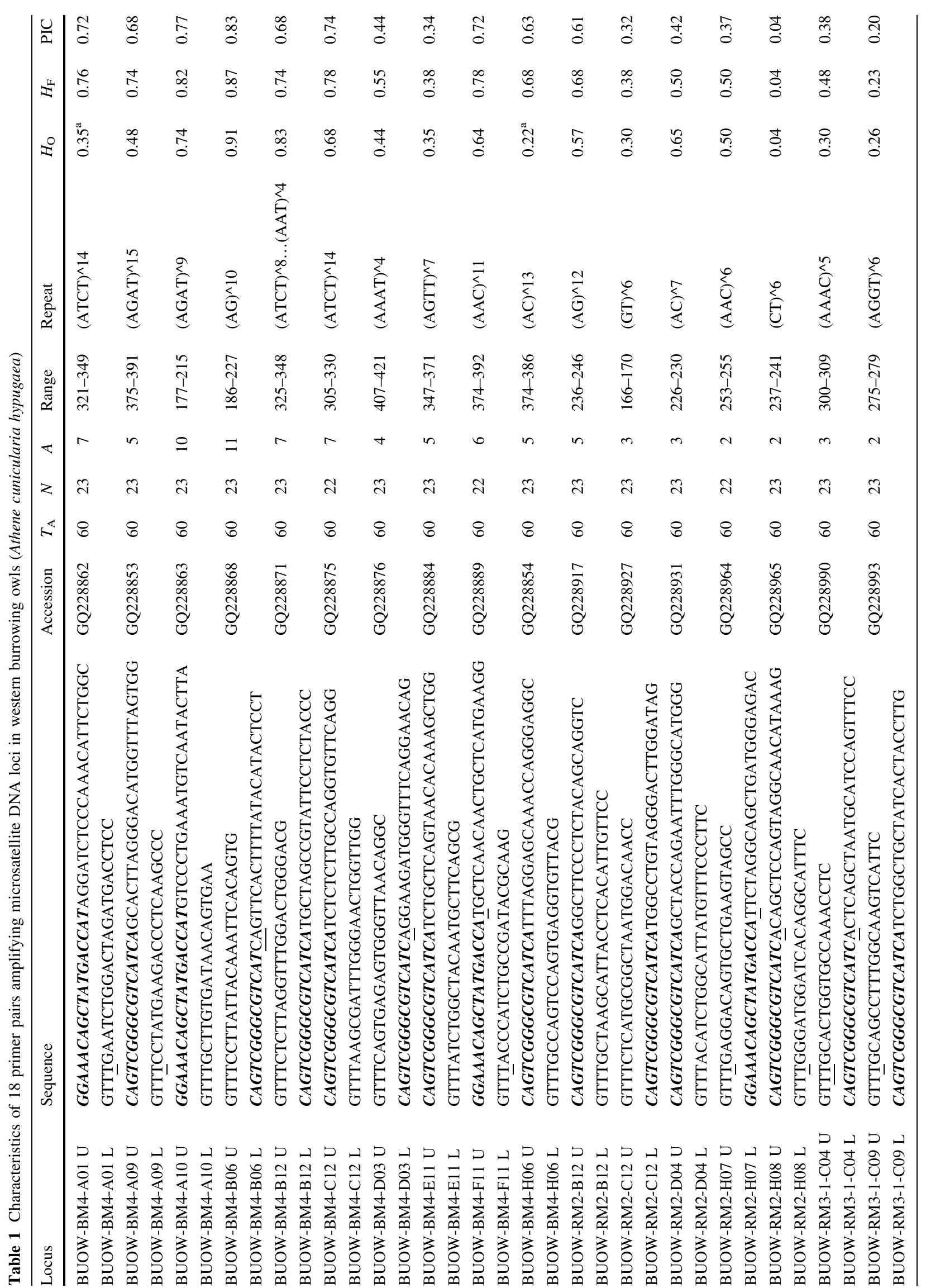


loci identified in Table 1 should be sufficient for future studies of burrowing owl mating behavior and relatedness when used alone or in combination with the microsatellite loci characterized by Korfanta et al. (2002).

Acknowledgments Financial support was provided by: USDA CSREES National Research Initiative to JRB, an EPA Star Fellowship to one of JRB's students, the US Bureau of Land Management, the Idaho Department of Fish and Game, Boise State University (BSU) Department of Biological Sciences, BSU Raptor Research Center funds to JRB, and setup funds for PAG from the University of California, Los Angeles. BSU's Institutional Animal Care and Use Committee approved the collection of burrowing owl blood samples used in this study, and we trapped and sampled burrowing owls under USGS Bird Banding Laboratory Permit \#22174 and Idaho Department of Fish and Game Scientific Collecting Permit \#930810 to JRB. PAG and JRB acquired funding for this research and provided the physical and intellectual resources for its pursuit; JW assisted with sample collection and preparation; $\mathrm{BCF}, \mathrm{AT}$, and $\mathrm{KT}$ conducted the microsatellite enrichment and data collection, BCF conducted the data analysis, and $\mathrm{BCF}, \mathrm{AT}, \mathrm{PAG}$, and JRB wrote the manuscript.

Open Access This article is distributed under the terms of the Creative Commons Attribution Noncommercial License which permits any noncommercial use, distribution, and reproduction in any medium, provided the original author(s) and source are credited.

\section{References}

Altschul SF, Gish W, Miller W et al (1990) Basic local alignment search tool. J Mol Biol 215:403-410

Benson DA, Karsch-Mizrachi I, Lipman DJ, Ostell J, Wheeler DL (2008) GenBank. Nucleic Acids Res 36:D25-D30

Blouin MS (2003) DNA-based methods for pedigree reconstruction and kinship analysis in natural populations. Trends Ecol Evol 18:503-511

Boutin-Ganache I, Raposo M, Raymond M et al (2001) M13-tailed primers improve the readability and usability of microsatellite analyses performed with two different allele-sizing methods. BioTechniques 31:24-28

Brownstein MJ, Carpenter JD, Smith JR (1996) Modulation of nontemplated nucleotide addition by $T a q$ polymerase: primer modifications that facilitate genotyping. BioTechniques 20: $1004-1010$

Conway CJ, Garcia V, Smith MD et al (2006) Comparative demography of burrowing owls in agricultural and urban landscapes in southeastern Washington. J Field Ornithol 77: 280-290

Don RH, Cox PT, Wainwright BJ et al (1991) Touchdown PCR to circumvent spurious priming during gene amplification. Nucleic Acids Res 19:4008

Faircloth BC (2008) MSATCOMMANDER: detection of microsatellite repeat arrays and automated, locus-specific primer design. Mol Ecol Res 8:92-94

Faircloth BC, Ramos A, Drummond H, Gowaty PA (2009) Isolation and characterization of microsatellite loci from blue-footed boobies (Sula nebouxii). Conserv Genet Resour 1:159-162

Glenn TC, Schable NA (2005) Isolating microsatellite DNA loci. In: Zimmer EA, Roalson EH (eds) Methods in enzymology 395, molecular evolution: producing the biochemical data, part B. Academic Press, San Diego, CA 
Haug EA, Millsap BA, Martell MS (1993) Burrowing owl (Athene cunicularia). In: A Poole (ed) The birds of North America online. Cornell Lab of Ornithology, Ithaca. doi:10.2173/bna.61

Kalinowski ST, Taper ML, Marshall TC (2007) Revising how the computer program CERVUS accommodates genotyping error increases success in paternity assignment. Mol Ecol 16:10991106

Klute DS, Ayers LW, Green MT, Howe WH, Jones SL, Shaffer JA, Sheffield SR, Zimmerman TS (2003) Status assessment and conservation plan for the western burrowing owl in the United States. US Department of Interior, Fish and Wildlife Service, Biol Tech Publ FWS/BTP-R6001-2003, Washington, DC

Korfanta NM, Schable NA, Glenn TC (2002) Isolation and characterization of microsatellite DNA primers in burrowing Owl (Athene cunicularia). Mol Ecol Notes 2:584-585

Korfanta NM, McDonald DB, Glenn TC (2005) Burrowing owl (Athene cunicularia) population genetics: a comparison of North American forms and migratory habits. Auk 122:464-478

Lantz SJ, Conway CJ, Anderson SH (2007) Multiscale habitat selection by burrowing owls in black-tailed prairie dog colonies. J Wildl Manage 71:2664-2672

Marshall TC, Slate J, Kruuk LEB et al (1998) Statistical confidence for likelihood-based paternity inference in natural populations. Mol Ecol 7:639-655
Milligan BG (2003) Maximum likelihood estimation of relatedness. Genetics 163:1153-1167

Moulton CE, Brady RS, Belthoff JR (2004) Territory defense of nesting burrowing owls: responses to simulated conspecific intrusion. J Field Ornithol 75:288-295

Moulton CE, Brady RS, Belthoff JR (2006) Association between wildlife and agriculture: underlying mechanisms and implication in burrowing owls. J Wildl Manage 70:708-716

Raymond M, Rousset F (1995) GENEPOP (version 1.2) population genetics software for exact tests and ecumenicism. J Hered 86:248-249

Restani M, Davies JM, Newton WE (2008) Importance of agricultural landscapes to nesting burrowing owls in the Northern Great Plains, USA. Landscape Ecol 23:977-987

Rice WR (1989) Analyzing tables of statistical tests. Evolution 43:223-225

Selkoe KA, Toonen RJ (2006) Microsatellites for ecologists: a practical guide using and evaluating microsatellite markers. Ecol Lett 9:615-629 